\title{
Elder abuse and its association with socio-demographic variables in India
}

\author{
Neha Seth $^{\mathrm{a}}$, Akhilesh Yadav ${ }^{\mathrm{a}}$, Nitesh K. Adichwal ${ }^{\mathrm{b}, *}$, Sachin B. Kamble ${ }^{\mathrm{c}}$ \\ a Department of Community Medicine, Institute of Medical Science, Banaras Hindu University, Varanasi, 221010, India \\ ${ }^{\mathrm{b}}$ Department of Statistics, Banaras Hindu University, Varanasi, 221010, India \\ ${ }^{\mathrm{c}}$ School of health system studies, Public Health, Tata Institute of Social Sciences, Mumbai, 400088, India
}

\section{A R T I C L E I N F O}

\section{Keywords:}

Elder abuse

Elderly

Socio demographic variables

India

\begin{abstract}
A B S T R A C T
Introduction: Elder abuse (abuse/violence/neglect or disrespect as defined by BKPAI data) among elderly is a deserted and overlooked issue especially in developing countries including India.

Aim: To assess the elder abuse and its association with socio-demographic factors among elderly population. Materials and Methods: This study comprises data from BKPAI 2011. Descriptive statistics, Chi-square test and binary logistic regression analysis have been used for the following study.

Results: A total of 9852 elderly people were included in this study which was carried out in seven states of India. The mean age of the study subjects was $68.04 \pm 7.29$ years. Among 9852 elderly people 10\% (987) were faced elder abuse. In unadjusted odd-ratio the status of elder abuse was found statistically significant with state, type of residence, sex, age group, caste, education, marital status, migration status, occupation, health condition and economic dependency etc. But in binary logistic regression analysis state, type of residence, sex, education, caste and their migration status were found statistically significant with elder abuse.

Conclusion: From the result of this study, the existence of "violence", "neglect", and "disrespect" within the society and community is approved. The problems of abuse among older persons were more mental than physical and elderly at getting older, without partner, with bad health condition, having less money or with no security are on more risk of getting abused.
\end{abstract}

\section{Introduction}

Ageing is a natural process of life which is common, usual, unavoidable, biological and universal phenomenon, and it affects every individual irrespective of their colour, caste, religion, economic status, etc. There are some contradictions on the boundary of elderly and it cannot be defined exactly because it does not have the same meaning in all societies. The United Nations uses the benchmark of 60 years of age or above to refer 'elderly. ${ }^{1}$. Here, the elderly is defined as the age of 60 years and above.

\subsection{Status of elderly population}

Worldwide, there were 901 million elderly population in 2015 and it is projected to grow 1400 million in 2030 and to 2100 million by $2050 .^{2}$ The elderly population of India was the second largest in the world in year 2012, after China ${ }^{3}$ and it is also have the same status in total population. Elderly population of the India has been increasing because the expected life span (an average Indian has increased from 36.7 years in 1951 to over 66.1 years in 2011) at birth has become longer due to better availability and utilization of health care facilities, increasing awareness, etc. It is projected to grow of elderly percentage contribution in total population from $8 \%$ in 2011 to $19 \%$ by $2050 .{ }^{4}$

Traditionally dominated by a joint family pattern, Indian society has stressed the value of children in the lives of their elderly parents and the change in family pattern (transition from joint family to nuclear family) is not swallowed by them easily, due to which older people are likely to expose insecurities regarding emotional, physical, financial morbidities. Also resulting multiple kinds of diseases added to elderly but still their problems are more psychological than physical like mental illness, depression, dementia and feeling of social isolation and lack of social support. 'Elder Abuse' is one of the important issue one often refrains from talking about or acknowledging that it exists. But, within the four walls and confines of one's home, a dark reality pervades. A detailed survey from HelpAge, to understand this growing crime against India's elders, by getting the elder perspective, their understanding and experiences have shockingly reports that, in 2014, half of India's elderly (50\%) surveyed reported experiencing abuse. $77 \%$ lived with their families. Three fifth $(60 \%)$ of the elderly consider verbal abuse as elder abuse while more than two fifth (48\%) feel physical abuse constitutes

\footnotetext{
* Corresponding author.

E-mail addresses: sethneha051@gmail.com (N. Seth), akhileshyadav99@gmail.com (A. Yadav), nnitesh139@gmail.com (N.K. Adichwal), sachinbk23@gmail.com (S.B. Kamble).
} 
elder abuse. More than one third each of the elderly feel that elder abuse constitutes emotional abuse (37\%), showing disrespect (36\%) and economic abuse (35\%). Nearly one fifth (19\%) of the elderly feel neglected. Therefore, the importance of Elder abuse (abuse/violence/ neglect or disrespect as defined by BKPAI data) among elderly cannot be overlooked.

\section{Review of literature}

Studies on the elderly population, either in the community, inpatient, outpatient and old age homes have shown that depression is the commonest mental illness in elderly subject. ${ }^{8},{ }^{9}$ Study indicate that the older individuals suffering from depression, poor health or physical impairments were more at risk of being abused than those of similar age and normal health status. This implies that an elderly with physical or mental impairments may be perceived as a burden by the care-givers. Such stressful and bitterness spills out in form of abuse and negligence of elderly. ${ }^{9}$ Social support has proved to promote successful ageing. ${ }^{10}, 11$ Studies have indicated that perception of absence of elder abuse in elderly is inversely related to the presence and severity of depressive symptoms. ${ }^{9},{ }^{12-15}$

\section{Need for the study}

The share of Old Age $(60+)$ population in total population is increasing and the share of Younger (0-14) is decreasing. Due to which there will be increase in Old Age Dependency Ratio and Children Dependency Ratio will be fail down. So there will be more demand for all kinds of services and a lot of investment has to go into dealing with elderly with various disabilities. As they will live longer, there will be longer investment required to maintain them. Elderly are weak and dependent on others and with addition of their low standard of living they became more vulnerable. For their well being it is necessary to understand the different influencing factors. However, there has been sparse study in India that has examined the role of elder abuse among elderly. So, this paper assesses the elder abuse and its association with socio-demographic factors among elderly population.

\section{Objectives}

1 To assess the socio-demographic variables among study subjects,

2 To assess the elder abuse and its association with socio-demographic factors among study subjects.

\section{Hypothesis}

There is an association between socio-demographic factors and elder abuse among elderly.

\section{Materials and methods}

The term 'Elder abuse' used in this study is based on its definition given by BKPAI. In the BKPAI survey, the respondents were asked two sets of questions regarding their experience of abuse since they were 60 years old and in the last month. The first question was "In the time since you completed 60 years of age have you faced any type of abuse or violence or neglect or disrespect by any person?" If the respondent answered 'Yes', a follow-up questions asked the type of abuse (physical abuse, verbal abuse, economic abuse, showing disrespect, neglect and other) and where it originated (within family, outside family, both within family and outside family). A further question asked, "Have you faced any type of physical or emotional abuse or violence in the last month?" The responses include: "(1) No; (2) Physical; (3) Emotional; (4) Both physical and emotional". All other types of violence other than physical were merged into emotional violence. If the respondent answered in the affirmative, follow-up questions elicited the source of
Table 1

Descriptive analysis of socio-demographic variables.

\begin{tabular}{|c|c|c|c|}
\hline Study Variables & Elderly (Number) & Elderly (\%) & Mean $\pm S D$ \\
\hline \multicolumn{4}{|l|}{ States } \\
\hline Himachal Pradesh & 1482 & 15 & \multirow[t]{7}{*}{$19.54 \pm 11.85$} \\
\hline Punjab & 1370 & 13.9 & \\
\hline West Bengal & 1275 & 12.9 & \\
\hline Orissa & 1481 & 15 & \\
\hline Maharashtra & 1435 & 14.6 & \\
\hline Kerala & 1365 & 13.9 & \\
\hline Tamilnadu & 1444 & 14.7 & \\
\hline \multicolumn{4}{|l|}{ Type of residence } \\
\hline Rural & 5138 & 52.2 & \multirow[t]{2}{*}{$1.48 \pm 0.50$} \\
\hline Urban & 4714 & 47.8 & \\
\hline \multicolumn{4}{|l|}{ Sex } \\
\hline Male & 4672 & 47.4 & \multirow[t]{2}{*}{$1.53 \pm 0.50$} \\
\hline Female & 5180 & 52.6 & \\
\hline \multicolumn{4}{|l|}{ Age group } \\
\hline $60-70$ & 7271 & 73.8 & \multirow[t]{3}{*}{$1.33 \pm 0.50$} \\
\hline $71-80$ & 1955 & 19.8 & \\
\hline $81+$ & 626 & 6.4 & \\
\hline \multicolumn{4}{|l|}{ Religion } \\
\hline Hindu & 7781 & 79 & \multirow[t]{2}{*}{$1.21 \pm 0.41$} \\
\hline Others & 2071 & 21 & \\
\hline \multicolumn{4}{|l|}{ Caste } \\
\hline SC/ST & 2383 & 24.8 & \multirow[t]{3}{*}{$2.15 \pm 0.79$} \\
\hline OBC & 3353 & 34.9 & \\
\hline Others & 3866 & 40.3 & \\
\hline \multicolumn{4}{|l|}{ Marital Status } \\
\hline Living with partner & 5886 & 59.8 & \multirow[t]{2}{*}{$1.40 \pm 0.50$} \\
\hline Living without partner & 3960 & 40.2 & \\
\hline \multicolumn{4}{|l|}{ Education } \\
\hline Illiterate & 4533 & 46 & \multirow[t]{2}{*}{$1.53 \pm 0.50$} \\
\hline Literate & 5319 & 54 & \\
\hline \multicolumn{4}{|l|}{ Elder Abuse } \\
\hline Never & 8792 & 89.9 & \multirow[t]{2}{*}{$1.10 \pm 0.30$} \\
\hline Yes & 987 & 10.1 & \\
\hline \multicolumn{4}{|l|}{ Migration } \\
\hline Migrated & 5957 & 60.5 & \multirow[t]{2}{*}{$1.40 \pm 0.49$} \\
\hline Not migrated & 3895 & 39.5 & \\
\hline \multicolumn{4}{|l|}{ Working Status } \\
\hline Yes & 2264 & 36.1 & \multirow[t]{2}{*}{$1.64 \pm 0.48$} \\
\hline No & 4001 & 63.9 & \\
\hline \multicolumn{4}{|l|}{ Reason for work } \\
\hline By choice & 660 & 29.2 & \multirow[t]{2}{*}{$1.71 \pm 0.45$} \\
\hline Compulsion & 1603 & 70.8 & \\
\hline General Health Condit & & & \\
\hline Good & 8143 & 82.7 & $1.17 \pm 0.38$ \\
\hline Bad & 1709 & 17.3 & \\
\hline
\end{tabular}

abuse which could include: "(1) Spouse; (2) Son; (3) Daughter; (4) Sonin-law; (5) Daughter-in-law; (6) Domestic helper; (7) Grandchildren; (8) Relatives; (9) Neighbours; (10) Other".

This study analyses is based on 'Building Knowledge Base on Ageing in India (BKPAI)' project. The BKPAI Survey was conducted in 2011 in seven major demographically advanced states of India-Himachal Pradesh, Punjab, West Bengal, Odisha, Maharashtra, Kerala and Tamil Nadu. This paper highlights the elder abuse and its association with various socio-demographic factors among elderly population in India. Descriptive statistics, Chi-square test and binary logistic regression analysis were used in the analysis.(Tables 1-3).

\section{Results}

A total of 9852 elderly people were included in this study which was carried out in seven states of India. The mean age of the study subjects was $68.04 \pm 7.29$ years. Among 9852 elderly people 10\% (987) were 
Table 2

Elder abuse and its association with various socio-demographic variables.

\begin{tabular}{|c|c|c|c|}
\hline Study Variables & Elder abuse present in number (\%) & $\chi^{2}$ & p-value \\
\hline \multicolumn{4}{|l|}{ State } \\
\hline Himachal Pradesh & $136(13.8)$ & 912.56 & 0.000 \\
\hline Punjab & $133(13.5)$ & & \\
\hline West Bengal & $94(9.5)$ & & \\
\hline Orissa & $108(10.9)$ & & \\
\hline Maharashtra & $448(45.4)$ & & \\
\hline Kerala & $43(4.4)$ & & \\
\hline Tamilnadu & $25(2.5)$ & & \\
\hline \multicolumn{4}{|l|}{ Type of residence } \\
\hline Rural & $611(61.9)$ & 41.67 & 0.000 \\
\hline Urban & $376(38.1)$ & & \\
\hline \multicolumn{4}{|l|}{ Sex } \\
\hline Male & $440(44.6)$ & 3.5 & 0.033 \\
\hline Female & $547(55.4)$ & & \\
\hline \multicolumn{4}{|l|}{ Age group } \\
\hline $60-70$ & $695(70.4)$ & 8.24 & 0.016 \\
\hline $71-80$ & $214(21.7)$ & & \\
\hline $81+$ & $78(7.9)$ & & \\
\hline \multicolumn{4}{|l|}{ Religion } \\
\hline Hindu & $762(77.2)$ & 2.55 & 0.061 \\
\hline Others & $225(22.8)$ & & \\
\hline \multicolumn{4}{|l|}{ Caste } \\
\hline SC/ST & $273(28.6)$ & 38.11 & 0.000 \\
\hline OBC & $248(26)$ & & \\
\hline Others & $434(45.4)$ & & \\
\hline \multicolumn{4}{|l|}{ Marital Status } \\
\hline Living with partner & $530(53.8)$ & 16.18 & 0.000 \\
\hline Living without partner & $455(46.2)$ & & \\
\hline \multicolumn{4}{|l|}{ Education } \\
\hline Illetrate & $576(58.4)$ & 67.2 & 0.000 \\
\hline Litrate & 411 (41.6) & & \\
\hline \multicolumn{4}{|l|}{ Working Status } \\
\hline Yes & 309 (44.5) & 24.03 & 0.000 \\
\hline No & 385 (55.5) & & \\
\hline \multicolumn{4}{|l|}{ Reason for work } \\
\hline By choice & $94(30.5)$ & 0.269 & 0.324 \\
\hline Compulsion & 214 (69.5) & & \\
\hline \multicolumn{4}{|c|}{ General Health Condition } \\
\hline Good & $211(21.4)$ & 13.10 & 0.000 \\
\hline Bad & $776(78.6)$ & & \\
\hline
\end{tabular}

faced elder abuse and out of which $44.6 \%$ (440) and 55.4\% (547) were males and females respectively. In unadjusted odd-ratio the status of elder abuse was found statistically significant with state, type of residence, sex, age group, caste, education, marital status, migration status, occupation, health condition and economic dependency etc. But in binary logistic regression analysis (Table 2) state, type of residence, sex, education, caste and their migration status were found statistically significant with elder abuse.

From Table 3, it is found that Females had 1.8 times higher chance to be abused as compare to males. Illiterate person had higher chance to be abused as compare to literate person. Elderly belonging to other caste have 1.9 times higher chance to be abused as compare to elderly who belongs to SC/ST caste. Elderly those did not migrate from their place were having less chance to be abused as compared to those who migrate from their place. These 5 variables altogether contribute $23 \%$ of abuse among elderly.

\section{Discussion}

From the above conclusion it is clear that there is significant increase in any type of violence or elder abuse against old people. This situation is sufficient to make us feel shame. Although the percentage of crime by unknown persons and professionals is quite high but alarming
Table 3

Binary logistic regression analysis controlling for various independent variables.

\begin{tabular}{|c|c|c|}
\hline \multirow[t]{2}{*}{ Independent variables } & \multicolumn{2}{|c|}{$\begin{array}{l}\text { Dependent variable: Elder abuse/violence/neglect or } \\
\text { disrespect }\end{array}$} \\
\hline & Odds Ratio & {$[95 \% \mathrm{CI}]$} \\
\hline \multicolumn{3}{|l|}{ State } \\
\hline \multicolumn{3}{|l|}{ Himachal Pradesh ${ }^{\circledast}$} \\
\hline Punjab & 1.515 & $(0.568,4.038)$ \\
\hline West Bengal & 0.867 & $(0.349,2.135)$ \\
\hline Orissa & 0.586 & $(0.219,1.569)$ \\
\hline Maharashtra & $0.973^{* * *}$ & $(1.022,3.063)$ \\
\hline Kerala & 0.640 & $(0.222,1.841)$ \\
\hline Tamilnadu & 0.707 & $(0.257,12.121$ \\
\hline \multicolumn{3}{|l|}{ Type of residence } \\
\hline \multicolumn{3}{|l|}{ Rural $^{\oplus}$} \\
\hline Urban & $0.718^{* *}$ & $(0.490,1.051)$ \\
\hline \multicolumn{3}{|l|}{ Sex } \\
\hline \multicolumn{3}{|l|}{ Male $^{\circledast}$} \\
\hline Female & $1.78^{* *}$ & $(1.022,3.063)$ \\
\hline \multicolumn{3}{|l|}{ Education } \\
\hline \multicolumn{3}{|l|}{ Illiterate ${ }^{\circledast}$} \\
\hline Literate & $0.653^{* *}$ & $(0.434,0.982)$ \\
\hline \multicolumn{3}{|l|}{ Caste } \\
\hline \multicolumn{3}{|l|}{$\mathrm{SC} / \mathrm{ST}^{\oplus}$} \\
\hline OBC & 1.096 & $(0.685,1.754)$ \\
\hline Others & $1.905^{* * *}$ & $(1.215,2.989)$ \\
\hline \multicolumn{3}{|l|}{ Migration Status } \\
\hline \multicolumn{3}{|l|}{ Migrated ${ }^{\circledast}$} \\
\hline Not migrated & $2.01 * * *$ & $(1.287,3.132)$ \\
\hline $\mathrm{R}^{2}=$ & 0.229 & \\
\hline
\end{tabular}

Significance levels: ***p $<0.01,{ }^{* * \mathrm{p}}<0.05$, $\mathrm{p}<0.1$.

${ }^{\circledR}:$ Referent group.

situation for us are the substantial incidences of crime against elderly people by family members, relatives, caregivers, nears and dears and even neighbors. In most of the cases reported so far perpetrators of crime are daughter-in-law, son and daughter. Another issue is related with apathetic attitude of society and non-reporting of such incidences. Only those cases, which go beyond the manageable limits are reported otherwise members of society and even sufferers just bear the pain as they feel going the matter outside the home is disgraceful. This nonreporting of cases also encourages perpetrators. Members of society just regard these incidences as family matter and do not take any action. The data reveals that emotional and economic dependence on the abusers is the main cause of abusing. Erosion of values, apathetic attitude of society, financial crises and health related issues of elders are some of the causes leading to the abuse. Absence of meaningful social attachment among older people and other family members to some extent is also responsible. Attitude and relational issues also add fuel to the fire. In most of the cases, elderly people were victimized of being alone as they have no choice to stay alone. Another issue is related to lack of awareness about redress mechanism of legal provisions for the incidences of elderly abuse. All these causes together make the situation worse. Simply presenting the data and fixing the responsibilities is not sufficient to deal with the problem. Active participation of community members is essential. Youths are to be sensitized. Even elderly people themselves must be made aware of legal provisions and to take cautionary measures. Senior citizen cells may be established in every district. Elderly helpline should effectively work. Police should also pay attention about the security of those who are living alone. Inter-personal relationship among family members should be strengthened. Speedy, effective, efficient redress mechanism is needed to ensure the safe and happy life to elderly people.

Facilities need to be provided to older people to meet likeminded people and spend their time doing some constructive social work. Need 
for professional caregivers is also essential, so that the members of the family who can help monetarily but not with time, and energy could get help and therefore some extent of abuse in that direction could be solved. Counseling needs have emerged as yet another major component of solving the problem of elder abuse. Counseling could prove to be an important component of family therapy and the end result could be beneficial for both the younger as well as the older generation.

The main point of discussion is why we are so unconcerned about those who have nurtured us. This growing empathy and negligence may be due to insensitive attitude, growing economic considerations and dependency. Government is trying its best at various levels like old age pensions are given to make them economic independent. Various NGOs also work and provide a helping hand to them. But it is the responsibility of each one of us to take some steps so that abusing may be reduced. It is true that government alone cannot solve the problem. The contribution of each one of us is necessary. Education has to sensitize youths and strengthen inter generation bonding. Youths are to be made sympathetic and responsible citizens. If such cases are found in the society, immediate social reporting and legal steps should be taken to redress the problem. It is very painful to see that those hands which nurtured us, made us develop what we are today, are begging for little affection, little care and due respect. We hope that this paper would serve as a catalyst for awakening the society and remind each one of us to give our parents everything of their share.

\section{Conclusion}

This study was designed with the overall aims of identifying the elder abuse and its association with various socio-demographic variables. The older persons were in the focus groups in the community. Elder abuse was linked to socio-demographic variables and was acknowledged by the participants of the study as something that happened in their community. From the result of this study, the existence of "violence", "neglect", and "disrespect" within the society and community is approved. The problems of abuse among older persons were more mental than physical and elderly at getting older, without partner, with bad health condition, having less money or with no security are on more risk of getting abused.

\section{Limitations}

Since it is a secondary analysis, it was tough to assess all dimensions of elder abuse. On the other hand the definitions defined by BKPAI have bounded the exploration of different dimensions of elder abuse. The data is collected from only seven states, so the figure and percentage was not applicable or comparable for India as a whole.

\section{References}

1. UNFPA. Ageing in the twenty-first century: a celebration and a challenge. 2012; 2012.

2. United Nations. Department of economic and social affairs, population division. World Population Ageing; 2015

3. Population Reference Bureau. India's aging population (today's research on aging, no. 25). 2012; 2012

4. United Nations Population Division (UN). World population prospects: the 2010 revision. 2011; 2011.

8. Nandi PS, Banerjee G, Mukherjee SP, Nandi S, Nandi DN. A study of psychiatric morbidity of the elderly population of a rural community in West Bengal. Indian $J$ Psychiatry. 1997;39(2):122-129.

9. Tiwari SC. Geriatric psychiatric morbidity in rural northen India: implications for the future. Int Psychogeriatr. 2000;12(01):35-48.

10. Fillit HM, Butler RN, O'Connell AW, et al. Achieving and maintaining cognitive vitality with aging. Mayo Clin Proc. 2002;77(7):681-696.

11. Fratiglioni L, Paillard-Borg S, Winblad B. An active and socially integrated lifestyle in late life might protect against dementia. Lancet Neurol. 2004;3(6):343-353.

12. Fiore J, Becker J, Coppel DB. Social network interactions: a buffer or a stress. Am J Commun Psychol. 1983;11(4):423-439.

13. Russell DW, Cutrona CE. Social support, stress, and depressive symptoms among the elderly: test of a process model. Psychol Aging. 1991;6(2):190.

14. Koenig HG, Westlund RE, George LK, Hughes DC, Blazer DG, Hybels C. Abbreviating the duke social support index for use in chronically ill elderly individuals. Psychosomatics. 1993;34(1):61-69.

15. Antonucci TC. Social relations an examination of social networks, social support. Handbook of the psychology of aging. 3. 2001; 2001:427. 